\title{
NOTE
}

\section{Participation of diatoms in the amino acid cycle of coastal waters; uptake and excretion in cultures*}

\author{
Wim Admiraal ${ }^{1}$, Remi W. P. M. Laane ${ }^{2}$ and Harry Peletier ${ }^{1}$ \\ ${ }^{1}$ Department of Marine Biology. State University of Groningen, 9750 AA Haren, The Netherlands \\ ${ }^{2}$ Netherlands Institute of Sea Research, $1790 \mathrm{AB}$ Texel, The Netherlands
}

\begin{abstract}
Micro-algae are thought to be involved in the turnover of pools of dissolved free amino acids (DFAA) in seawater either by their excretion or by the uptake of these compounds. Our study showed that, in vitro, 3 benthic diatom species were able to deplete small additions of individual Lamino acids down to concentrations below 10 to $40 \mathrm{nmol}^{-1}$. as determined by HPLC. When nitrogen was limited, all test species scavenged their media for 10 or 11 amino acids added but Amphiprora cf. paludosa assimilated 3 amino acids also in the presence of surplus nitrate. Navicula salinarum took up all 10 amino acids supplied, whereas Nitzschia closterium assimilated none of them, when nitrate was present. Excretion of DFAA could not be detected in the medium of growing nitrate-sufficient cultures; $N$. closterium, $N$. salinarum and A. cf. paludosa excreted respectively less than $0.03,0.05$ and $0.1 \%$ of the cellular nitrogen as amino acids. Only silicate deprivation induced $A$. cf. paludosa to excrete $1 \%$ cellular nitrogen as DFAA. The results show that benthic diatom populations may act as net consumers of DFAA, even when the concentrations are as low as 100 to $1,000 \mathrm{nmol} \mathrm{l}^{-1}$, the range reported for nearshore seawater and the porewater of mudflats.
\end{abstract}

Amino acids belong to the small fraction of dissolved organic compounds in seawater that are subject to rapid recycling (Laane, 1983). The concentrations of free dissolved amino acids range from approximately $100 \mathrm{nmol} \mathrm{l}^{-1}$ in coastal waters (Riley and Segar, 1970; Jørgensen, 1982) to several $\mu \mathrm{mol} \mathrm{l}^{-1}$ in interstitial water (Christensen and Blackburn, 1980; Jørgensen et al., 1981). By adding ${ }^{14} \mathrm{C}$-labelled amino acids to water samples and measuring the rate of uptake by suspended organisms it has been shown that the cycling of dissolved free amino acids (DFAA) is a quantitatively important feature of the marine ecosystem (Crawford et al., 1974; Williams et al., 1976; Jørgensen, 1982). It is generally assumed that micro-algae play an important role as producers of DFAA by their exuda-

\footnotetext{
- Contribution No. 74 of the project Biological Research EmsDollard Estuary
}

tion or by the decay of senescent cells, whereas bacteria are thought to be the main consumers of DFAA. But this concept should be treated with caution. The quantitative importance of phytoplankton extracellular release has been studied extensively. Whereas the release of amino acids by phytoplankton has occasionally been documented (Watt, 1969; Gocke, 1970; Hammer and Brockmann, 1983; Poulet and Martin-Jézéquel, 1983), information on benthic micro-algae is lacking. Further, there is growing evidence that many micro-algal species, especially the benthic ones, are able to utilize amino acids (and other organic nitrogen sources) as sole source of nitrogen (Bonin and Maestrini, 1981). However, the concentrations of DFAA, used in these studies are usually much higher than those encountered in seawater. Therefore, it seemed important to ascertain whether benthic micro-algae excrete significant amounts of DFAA and whether ecologically significant amino acid concentrations can be utilized by the algae simultaneously. We postulate that exudation and uptake of DFAA might reflect shifting equilibria between cellular and extra-cellular pools of amino acids (Admiraal and Werner, 1983).

Three species of diatoms were isolated from the Ems-Dollard Estuary. Navicula salinarum Grunow was isolated from an organically polluted mudflat and showed rapid heterotrophic and photo-heterotrophic growth on an amino acid mixture or glucose, when these substrates were added in high concentrations (Admiraal and Peletier, 1979). Nitzschia closterium (Ehrenberg) W. Smith and Amphiprora cf. paludosa W. Smith were isolated from the mudflat surface, but are also frequently encountered in the estuarine phytoplankton. $N$. closterium, but not A. paludosa, showed slow heterotrophic growth in cultures (Admiraal and Peletier, 1979). The 3 species were grown in axenic batch-cultures following techniques described pre- 
viously (Admiraal and Werner, 1983). Exponentially growing nitrate-sufficient cells were inoculated aseptically in a series of 4 different media, 2 with sufficient concentrations of nitrate $\left(675 \mu \mathrm{mol} \mathrm{l^{-1 }}\right)$ and two with limiting ( 25 to $50 \mu \mathrm{mol} 1^{-1}$ ) concentrations of nitrate. A supplement of 10 or $11 \mathrm{~L}$-amino acids was added to one nitrate-rich medium and to one nitrate-poor medium. The amino-acids, added in concentrations of ca. $400 \mathrm{nmol} \mathrm{l}^{-1}$ each, were glycine (gly), threonine (thr), valine (val), arginine (arg), leucine (leu), isoleucine (ile), serine (ser), glutamic acid (glu), aspartic acid (asp), alanine (ala) and histidine (his). The cultures were incubated on a rotary shaker at $14^{\circ} \mathrm{C}$. They received $100 \mu \mathrm{E} \mathrm{m}^{-2} \mathrm{~s}^{-1}$ of light during $14 \mathrm{~h} \mathrm{~d}^{-1}$. Samples of the cultures were centrifuged at $1,000 \mathrm{~g}$ for $20 \mathrm{~min}$ to separate cells from medium. Concentrations of nitrate and silicate in the media were determined using automated analysis, following Strickland and Parsons (1972). The concentrations of individual amino acids were measured by HPLC separation of o-phthal dialdehyde derivates, following Lindroth and Mopper (1979).

The 3 diatom species assimilated the mixtures of the amino acids in the media after exhaustion of the nitrate

A

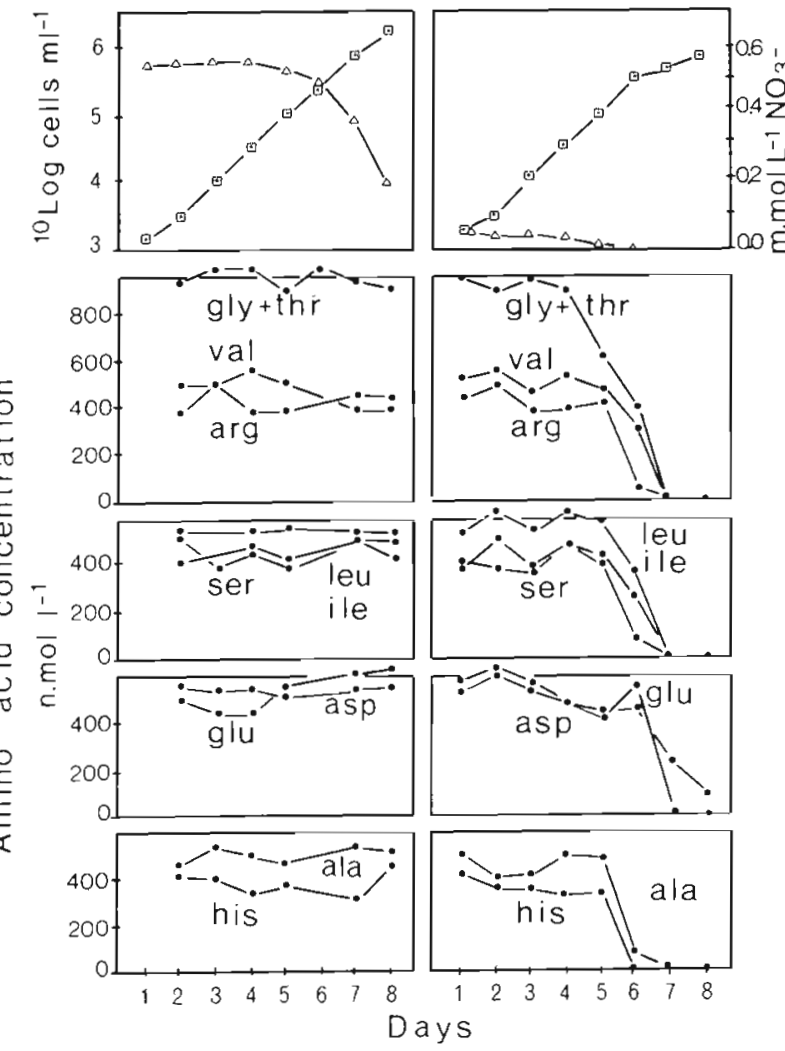

Fig. 1. Nitzschia closterium. Concentrations of cells (অ), nitrate $(\Delta)$ and individual amino acids during a growth cycle in nitrate-rich (A) and nitrate-poor (B) medium, both supplied with a mixture of L-amino acids

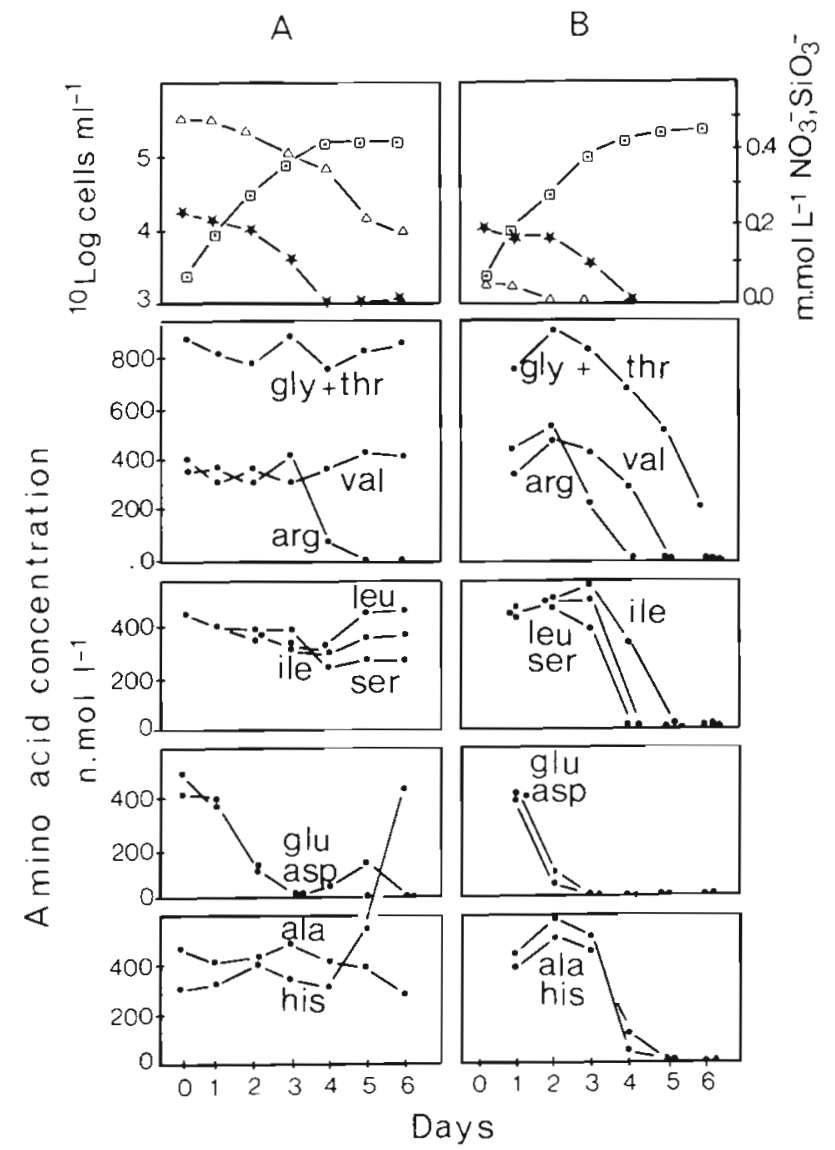

Fig. 2. Amphiprora cf. paludosa. Conditions as in Fig. 1. $\mathrm{SiO}_{3}^{-}$: concentration of silicate $(\star)$

(Fig. 1 to 3). Under conditions of sufficient nitrogen, the species responded differently. Nitzschia closterium (Fig. 1) did not utilize the added amino acids, whereas Amphiprora cf. paludosa (Fig. 2) depleted the pools of glutamic acid, aspartic acid and arginine in an early growth stage, but left the other amino acids. When nitrogen supply was sufficient, Navicula salinarum (Fig. 3) slowly scavenged its culture medium for all the amino acids added, but when nitrogen was limited it scavenged rapidly. The differing responses of the test species confirm earlier observations on the diversity in the utilization of organic nitrogen between microalgae (Wheeler et al., 1974; Lewin and Hellebust, 1978; Bonin and Maestrini, 1981).

Amino acid pools in the cultures were depleted to undetectable levels, i.e. to concentrations below 10 to $40 \mathrm{nmol}^{-1}$. Several amino acids have been measured in higher concentrations in nearshore seawater and interstitial water (Riley and Segar, 1970; Christensen and Blackburn, 1980; Jørgensen, 1982). These concentrations are generally regarded as threshold concentrations, indicating that they are barely sufficient to maintain bacterial growth. Our results show that certain 
A

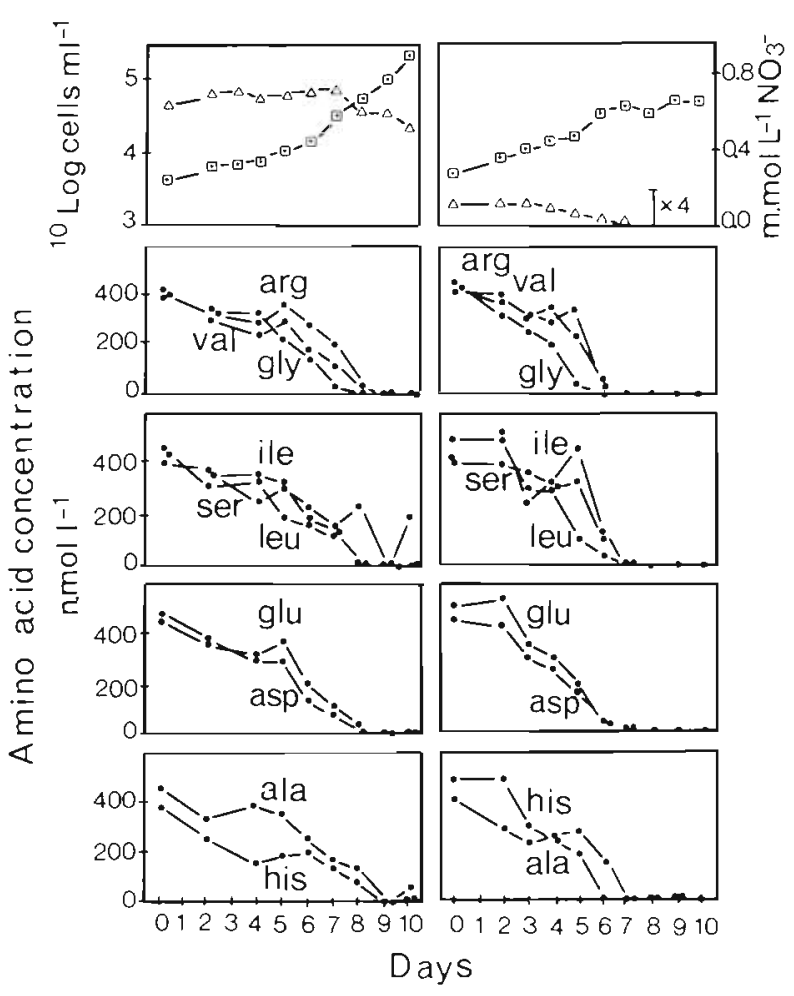

Fig. 3. Navicula salinarum. Conditions as in Fig. 1

micro-algae are able to reduce the amino acid levels down to, or below these so-called threshold levels. In agreement, an earlier observation (North, 1975) showed that $50 \%$ of the dissolved fluorescamine-positive compounds (including DFAA) in seawater was assimilated by the flagellate alga Platymonas sp.

Several technical points need further elucidation: (1) In the present study only L-amino acids were used, whereas in the natural habitat the contribution of Damino acids can be significant (Lee and Bada, 1977). The 2 enantiomeric forms of amino acids may be utilized with differing efficiencies by algae and bacteria; therefore, the exclusive use of L-forms in field and laboratory experiments is a potential source of error. (2) In natural seawater, amino acids, measured as DFAA, may be present in a complexed, biologically unavailable form (Christensen and Blackburn, 1980); this would lower the supposed threshold levels for bacteria and algae even further than current chemical determinations suggest. (3) Incorporation of amino acids by natural micro-algal populations is probably an extremely variable process, dependent on species composition and nutritional state. Furthermore, the assimilation of DFAA cannot be established with certainty using ${ }^{14} \mathrm{C}$-lạbelled amino acids (Crawford et al., 1974; Williams et al., 1976), unless extra-cellular deamination (Lee and Bada, 1977) and amino acid release by the micro-algae are taken into account.
None of the 3 test species excreted detectable concentrations of DFAA, when growing in nitrate-sufficient or nitrate-deprived medium. Less than $0.03,0.05$ and $0.1 \%$ of the particulate nitrogen was excreted as amino acids in cultures of Nitzschia closterium, Navicula salinarum and Amphiprora cf. paludosa, respectively. These percentage nitrogen excretions were much lower as the percentage excretions of organic carbon that are mostly found in the range of 1 to $10 \%$ in many micro-algal species. Only silicatedeprived cells of $A$. cf. paludosa (Fig. 2) excreted detectable concentrations of DFAA, amounting to $1 \%$ of the particulate nitrogen. In the latter case, serine, glutamic acid and alanine, histidine (or glutamine) were the main amino acids released.

Individual free amino acids are present in nitrogensufficient diatom cells in concentrations over $1 \mathrm{mmol} \mathrm{l}^{-1}$ (Dortch, 1982). These concentrations are a factor of $10^{5}$ higher than those just detectable in our amino acid analysis. Hence a diatom such as Nitzschia closterium seems to be nearly impermeable to amino acids, even under nitrogen-sufficient conditions. This is not true of all algal species: in cultures of the symbiotic green alga Chlamydomonas provasolii, amino acids were prominent among the exudates (Saks, 1982). Excretion of DFAA may be a normal attribute of planktic diatoms as it has been established now for several cultured species (Hammer and Brockmann, 1983; Poulet and Martin-Jézéquel, 1983; Admiraal et al., unpubl.). In accordance, increased DFAA concentrations have been correlated with phytoplankton blooms (Hammer and Eberlein, 1981; Keller et al., 1982). It is evident that a culture study such as ours gives no unequivocal proof of ecological mechanisms operating in natural systems. Yet, the present results support the hypothesis that healthy populations of benthic diatoms are insignificant as producers of DFAA in the estuarine ecosystem. These micro-algae may even function as net consumers of amino acids.

Acknowledgements. We are indebted to R. Wiersma for support with the determinations of inorganic nutrients and to Professor Dr. D. Werner and Dr. W. Gieskes for discussion and critical comments on the manuscript.

\section{LITERATURE CITED}

Admiraal, W., Peletier, H. (1979). Influence of organic compounds and light limitation on the growth rate of estuarine benthic diatoms. Br. phycol. J. 14:197-206

Admiraal, W., Werner, D. (1983). Utilization of limiting concentrations of ortho-phosphate and production of extracellular organic phosphates in cultures of marine diatoms. J. Plankton Res. 5: 495-513

Bonin, D. J., Maestrini, S. Y. (1981). Importance of organic 
nutrients for phytoplankton growth in natural environments, implications for algal species succession. In: Platt, T. (ed.) Physiological basis of phytoplankton ecology. Can. Bull. Fish aquat. Sci. 210: 279-291

Christensen, D., Blackburn, T. H. (1980). Tumover of tracer $\left({ }^{14} \mathrm{C},{ }^{3} \mathrm{H}\right.$ labelled) alanine in inshore marine sediments. Mar. Biol. 58: 97-103

Crawford, C. C., Hobbie, J. E., Webb, K. L. (1974). The utilization of dissolved free amino acids by estuarine microorganisms. Ecology 55: 551-563

Dortch, Q. (1982). Effect of growth conditions on accumulation of internal nitrate, ammonium, amino acids, and protein in three marine diatoms. J. exp. mar. Biol. Ecol. 61: 243-264

Gocke, K. (1970). Untersuchungen über Abgabe und Aufnahme von Aminosäuren und Polypeptiden durch Planktonorganismen. Arch. Hydrobiol. 67: 285-367

Hammer, K. D., Eberlein, K. (1981). Parallel experiments with Thalassiosira rotula in outdoor plastic tanks: development of dissolved free amino acids during an algae bloom. Mar. Chem. 10: 533-544

Hammer, K. D., Brockmann, U. H. (1983). Rhythmic release of dissolved free amino acids from partly synchronized Thalassiosira rotula under nearly natural conditions. Mar. Biol. 74: 305-312

Jørgensen, N. O. G., Lindroth, P., Mopper, K. (1981). Extraction and distribution of free amino acids and ammonium in sediment interstitial waters from the Limfjord, Denmark. Oceanologica Acta 4: 465-474

Jørgensen, N. O. G. (1982). Heterotrophic assimilation and occurrence of dissolved free amino acids in a shallow estuary. Mar. Ecol. Prog. Ser. 8: 145-159

Keller, M. D., Mague, T. H., Badenhausen, M., Glover, H. E. (1982). Seasonal variations in the production and consumption of amino acids by coastal microplankton. Estuar. coast. Shelf. Sci. 15: 301-315

Laane, R. W. P. M. (1983). Seasonal distribution of dissolved and particulate amino acids in the Ems-Dollard estuary. Oceanologica Acta 6: 105-109
Lee, C., Bada, J. L. (1977). Dissolved amino acids in the equatorial Pacific, the Sargasso Sea, and Biscayne Bay Limnol. Oceanogr. 22: 502-510

Lewin, J., Hellebust, J. A. (1978). Utilization of glutamate and glucose for heterotrophic growth by the marine pennate diatom Nitzschia laevis. Mar. Biol. 47: 1-7

Lindroth, P., Mopper, K. (1979). High performance liquid chromatographic determination of subpicomole amounts of amino acids by precolumn fluorescence derivatization with o-phthaldialdehyde. Analyt. Chem. 51: 1667-1674

North, B. B. (1975). Primary amines in California coastal waters: utilization by phytoplankton. Limnol. Oceanogr 20: $20-27$

Poulet, S. A., Martin-Jézéquel, V. (1983). Relationships between dissolved free amino acids, chemical composition and growth of the marine diatom Chaetoceros debile. Mar. Biol. 77: 93-100

Riley, J. P., Segar, D. A. (1970). The seasonal variation of the free and combined dissolved amino acids in the Irish Sea J. mar biol. Ass U. K. 50: 713-720

Saks, N. M. (1982). Primary production and release of assimilated carbon by Chlamydomonas provasolii in culture. Mar. Biol. 70: 205-208

Strickland, J. D. H., Parsons, T. R. (1972). A practical handbook of seawater analysis. Bull. Fish. Res. Bd Can. 167 ; $1-310$

Watt, W. D. (1969). Extracellular release of organic matter from two freshwater diatoms. Ann. Bot. 33: 427-437

Wheeler, P. A., North, B. B., Stephens, G. C. (1974). Amino acid uptake by marine phytoplankters. Limnol. Oceanogr 19: 249-259

Wheeler, P., North, B., Littler, M., Stephens, G. (1977). Uptake of glycine by natural phytoplankton communities. Limnol. Oceanogr. 22: 900-910

Williams, P. J. Le B., Berman, T., Holm-Hansen, O. (1976) Amino acid uptake and respiration by marine heterotrophs. Mar Biol. 35: 41-47

Accepted for printing on November 7,1983 